\title{
Pengaruh Penggunaan Media Manipulatif terhadap Hasil Belajar Matematika Siswa Kelas V SDN 52 Kota Bengkulu
}

\author{
Ike Kurniawati \\ Universitas Bengkulu \\ ikekurniawati142@yahoo.com \\ V. Karjiyati \\ Universitas Bengkulu \\ vkarjiyati@gmail.com \\ Dalifa \\ Universitas Bengkulu \\ dalifa.abdullah@gmail.com
}

\begin{abstract}
This study aims to determine the effect of manipulative media on student learning outcomes in learning mathematics class $V$ SDN 52 Kota Bengkulu. This research is a quantitative type. The research method used is Quasi Experimental with design type The Matching Only PretestPosttest Control Group Design. The population in this study is all students of grade V SDN Kota Bengkulu using KTSP. While the sample of class $V$ students in SDN 52 Kota Bengkulu consists of VA, VB, VC and $V D$. The sampling technique uses cluster random sampling. From the scramble obtained VC class of 28 students as experiment class and VA class amounted to 29 students as control class. The research instrument used in the form of cognitive learning result test is in the form of multiple choice questions given through pretest and posttest in the experimental class and control class. Data of this research are analyzed by using descriptive analysis and inferential analysis that is t-test. Data of research result which is processed by using $t$-test is got tcount value 2,84 and $t$ table value equal to 1,625. Systematically seen $t$ count $(2.84)>t$ table $(1,625)$ at $5 \%$ significant level, it can be concluded that there is influence of the use of manipulative media on student learning outcomes on learning matemtika class V SDN 52 Kota Bengkulu.
\end{abstract}

Keywords: Manipulative Media, Learning Outcomes, Mathematics

\footnotetext{
Abstrak

Penelitian ini bertujuan untuk mengetahui pengaruh media manipulatif terhadap hasil belajar siswa dalam pembelajaran matematika kelas $\mathrm{V}$ SDN 52 Kota Bengkulu. Penelitian ini adalah tipe kuantitatif. Metode penelitian yang digunakan adalah Quasi Experimental dengan jenis desain The Matching Only Pretest-Posttest Control Group Design. Populasi dalam penelitian ini adalah semua siswa kelas V SDN Kota
} 
Bengkulu menggunakan KTSP. Sedangkan sampel siswa kelas V di SDN 52 Kota Bengkulu terdiri dari VA, VB, VC dan VD. Teknik pengambilan sampel menggunakan cluster random sampling. Dari scramble diperoleh kelas VC dari 28 siswa sebagai kelas eksperimen dan kelas VA berjumlah 29 siswa sebagai kelas kontrol. Instrumen penelitian yang digunakan dalam bentuk tes hasil belajar kognitif adalah dalam bentuk soal pilihan ganda yang diberikan melalui pretest dan posttest di kelas eksperimen dan kelas kontrol. Data penelitian ini dianalisis dengan menggunakan analisis deskriptif dan analisis inferensial yaitu uji-t. Data hasil penelitian yang diolah dengan menggunakan uji-t diperoleh nilai thitung 2,84 dan nilai t tabel sebesar 1,625. Secara sistematis terlihat $\mathrm{t}$ hitung $(2,84)>\mathrm{t}$ tabel $(1,625)$ pada taraf signifikan $5 \%$, dapat disimpulkan bahwa ada pengaruh penggunaan media manipulatif terhadap hasil belajar siswa pada pembelajaran matemtika kelas V SDN 52 Kota Bengkulu.

Kata kunci: Media Manipulatif, Hasil Belajar, Matematika

\section{Pendahuluan}

Matematika memiliki peranan yang penting dalam kehidupan yaitu dapat digunakan dalam memecahkan masalah kehidupan sehari-hari, matematika juga mengajarkan seseorang yang mempelajarinya untuk bisa berpikir logis, kritis, analisis, sistematis, dan kreatif. Pada kenyataannya nilai matematika siswa di Indonesia tergolong rendah. Berdasarkan hasil survey Trends in International Mathematics and Science Study (TIMSS) pada tahun 2015 menunjukkan prestasi siswa Indonesia bidang matematika mendapat peringkat 45 dari 50 negara dengan skor 397. Hal yang tidak jauh berbeda juga terlihat pada hasil penelitian yang dilakukan oleh Programme for International Student Assesment (PISA) pada tahun 2015, Indonesia berada pada peringkat 62 dari 70 negara dalam mata pelajaran matematika dengan skor 386 (OECD: 2015).

Matematika memiliki objek kajian yang bersifat abstrak. Sesuai dengan pendapat Sundayana (2013: 2) matematika memiliki tingkat kesulitan yang tinggi karena obyeknya yang bersifat abstrak tetapi matematika perlu dipelajari walaupun sulit.

Pada umumnya guru mengajarkan matematika tidak menerapkan konsep terlebih dahulu melainkan hanya menjelaskan materi, memberi contoh soal, menjelaskan cara penyelesaian soal dan diakhiri dengan memberikan latihan, akibatnya siswa menjadi kurang tertarik, bosan, memiliki kesibukan sendiri-sendiri, dan pembelajaran menjadi tidak menyenangkan, sehingga materi tidak dapat dipahami oleh siswa.

Konsep-konsep matematika dapat dipahami dengan mudah bila disajikan dalam bentuk kongkret, lalu diarahkan pada tahapan semi kongkret, dan pada akhirnya siswa dapat berfikir dan memahami matematika secara abstrak. Hal ini sesuai dengan Piaget (Syah: 2015: 26) yang mengemukakan bahwa karakteristik siswa Sekolah Dasar berusia 7 sampai 11 tahun yang berada dalam tahap berpikir operasional konkret, pada tahap ini siswa baru mampu berfikir sistematis mengenai benda-benda dan peristiwa-peristiwa yang kongkrit.

Dalam Kurikulum Tingkat Satuan Pendidikan (KTSP) kelas V semester 2 sekolah dasar terdapat Standar Kompetensi 6. Memahami sifat-sifat bangun dan hubungan antar bangun dengan Kompetensi Dasar 6.3 Menentukan jaring-jaring berbagai bangun ruang sederhana. Untuk mengajarkan jaring-jaring bangun ruang di tingkat Sekolah dasar, dilakukan dengan mengenalkan berbagai bangun ruang, menganalisis ciri-cirinya dan mengetahui hubungan ciri-ciri dari bangun ruang, 
sehingga dapat menemukan jaring-jaring berbagai bangun ruang. Hal ini sejalan dengan Van Hiele (Muhsetyo: 2009: 1.14) yang mengemukakan bahwa dalam pembelajaran geometri dimulai dari tahap visualisai, tahap analisis, tahap abstraksi, tahap deduksi dan tahap rigor atau matematis.

Untuk mecapai keberhasilan dalam mengajarkan konsep jaring-jaring bangun ruang juga diperlukan media pembelajaran. Media pembelajaran berperan sebagai alat bantu dalam proses pembelajaran. Media pembelajaran yang digunakan untuk mengajarkan konsep jaring-jaring bangun ruang yaitu media manipulatif. Media manipulatif adalah media pembelajaran yang dapat dimanipulasi oleh siswa, yaitu dibalik, digeser, dipotong, dan direbahkan. Menurut Muhsetyo (2009: 2.20) media manipulatif dalam pembelajaran matematika SD adalah media yang dapat dimainmainkan, dipegang, dipindah-pindah, dipasang, dibolak-balik, diatur/ditata dan dilipat/dipotong oleh siswa.

Media manipulatif dapat mengkonkretkan obyek matematika yang bersifat abstrak. Brunner (Runtukahu: 2016: 69) menyatakan bahwa anak usia Sekolah Dasar berada pada tahap enaktif. Artinya pada tahap ini siswa langsung terlibat dalam memanipulasi obyek-obyek matematika, sehingga media manipulatif bermanfaat dalam proses pembelajaran jaring-jaring bangun ruang karena dengan media manipulatif bangun ruang siswa akan terlibat langsung dalam memanipulasi obyek matematika yang abstrak dan dapat menemukan konsep sendiri dalam proses pembelajaran dan meyebabkan hasil belajar menjadi lebih meningkat.

Hasil belajar adalah kemampuan yang diperoleh siswa secara keseluruhan yang menjadi alat ukur perubahan perilaku yang telah terjadi pada diri siswa setelah melakukan proses pembelajaran.

Menurut Bloom (Sudjana, 2009: 22) hasil belajar terbagi menjadi tiga ranah yaitu ranah kognitif, ranah afektif dan ranah psikomotorik. Menurut Anderson (2017: 100), aspek kognitif dibedakan atas enam jenjang yang diurutkan sebagai berikut: 1) mengingat (remembering) 2) memahami (understanding) 3) mengaplikasikan (applying) 4) menganalisis (analyzing) 5) mengevaluasi (evaluating) 6) mencipta (creating). Hasil belajar yang akan diukur pada penelitian ini adalah hasil belajar kognitif mata pelajaran matematika yang meliputi mengaplikasikan (C3) menganalisis (C4) dan mengevaluasi (C5). Instrument digunakan untuk mengukur hasil belajar siswa pada aspek kognitif dengan jenjang pengetahuan meliputi pengetahuan faktual, konseptual, prosedural dan metakognitif.

Hasil penelitian Lubis (2014) tentang "Pengaruh media manipulatif pada pembelajaran matematika terhadap hasil belajar siswa kelas V SD" mengemukakan bahwa pembelajaran dengan menggunakan media manipulatif memberikan pengaruh positif terhadap hasil belajar siswa pada pembelajaran matematika. Hal ini diperkuat oleh, M. Boggan dkk (2013) yang mengemukakan bahwa "Manipulatives help students learn by allowing them to move from concrete experiences to abstract reasoning" pendapat tersebut menyatakan bahwa media manipulatif dapat membantu siswa dalam pembelajaran dan memungkinkan mereka untuk beralih dari pengalaman konkret ke penalaran abstrak, sehingga dengan penggunaan media manipulatif hasil belajar akan lebih baik dan menepiskan anggapan bahwa belajar matematika itu sulit dan tidak menarik.

Berdasarkan latar belakang di atas, maka rumusan masalah dalam penelitian ini adalah "Apakah terdapat pengaruh penggunaan media manipulatif terhadap hasil belajar siswa pada pembelajaran matematika siswa kelas V SD N 52 kota Bengkulu?" 
Adapun tujuan penelitian ini adalah untuk mengetahui apakah terdapat pengaruh penggunaan media manipulatif terhadap hasil belajar siswa pada pembelajaran matematika kelas V SD N 52 kota Bengkulu.

\section{Metode}

Jenis penelitian yang digunakan dalam penelitian ini merupakan penelitian kuantitatif karena data yang diolah dalam penelitian ini berupa angka/ numerik yang diperoleh dari hasil belajar kognitif siswa. Menurut Sugiyono (2013: 8) penelitian kuantitatif merupakan jenis penelitian yang digunakan untuk meneliti pada populasi atau sampel tertentu, pengumpulan data menggunakan instrumen penelitian, analisis data bersifat statistik, untuk tujuan menguji analisis yang telah diteliti.

Metode yang digunakan dalam penelitian ini adalah metode eksperimen semu (quasy experiment) Pelaksanaan metode quasi eksperimen ini bertujuan untuk melihat pengaruh akibat adanya perlakuan berbeda yang diberikan kepada dua kelas, yaitu kelas eksperimen dan kelas kontrol. Dalam menentukan pengaruh penggunaan media papan berpaku terhadap hasil belajar matematika siswa atau menguji hipotesis tentang ada dan tidaknya pengaruh perlakuan yang diberikan. Hasil dari penelitian quasi eksperimen tersebut akan menjawab hipotesis yang telah diajukan untuk mengetahui apakah hipotesis diterima atau ditolak.

Fraenkel dan Wallen (Winarni 2011: 94) populasi adalah kelompok yang menarik peneliti, dimana kelompok tersebut oleh peneliti dijadikan obyek untuk menggeneralisasikan hasil penelitian. Populasi dalam penelitian ini adalah seluruh siswa kelas V SDN Kota Bengkulu yang menggunakan kurikulum tingkat satuan pendidikan (KTSP).

Sampel merupakan bagian yang akan diteliti dan mewakili dari populasi yang ada. Menurut Winarni (2011: 97) sampel merupakan bagian integral yang tak dapat dipisahkan dengan populasi dan merupakan cermin dari populasi "potret" sampel seharusnya itulah "wajah" populasi. Penelitian menggunakan sampel memberikan beberapa keuntungan, seperti hemat waktu, biaya maupun tenaga dan mempertinggi kecermatan. Sampel dalam penelitian ini ditentukan dengan menggunakan teknik Cluster Random Sampling. Sampel pada penelitian ini yaitu siswa kelas VA dan VC SDN 52 Kota Bengkulu.

Instrumen penelitian adalah suatu alat yang digunakan untuk mengukur fenomena alam maupun sosial yang diamati. Secara spesifik semua fenomena ini disebut variabel penelitian (Sugiyono, 2013: 102). Dalam penelitian ini, instrumen yang digunakan adalah tes hasil belajar matematika siswa, berbentuk tes obyektif sebelum dan sesudah mengikuti pembelajaran, dengan menggunakan media manipulatif model bangun ruang. Bobot skor setiap soalnya lima dengan alternatif jawaban (a, b, c, dan d).

Teknik pengumpulan data diawali dengan melakukan uji coba instrumen. Hasil uji coba, di lakukan uji validitas, reliabilitas, taraf kesukaran dan daya pembeda. Sebanyak 20 soal dikatagorikan valid dan dapat digunakan untuk pretest dan posttest. Pretest dan posttest yang digunakan dengan bentuk soal yang sama, soal diberikan kepada sampel sesuai dengan konsep yang diajarkan selama penelitian berlangsung. Sumber data yang diperoleh diambil dari setiap siswa yang menjadi sampel dan siswa diminta untuk menjawab soal-soal yang diberikan. Pemberian soal tes dan waktu pelaksanaan pengambilan data dilakukan sesuai dengan jadwal mata pelajaran yang ada di sekolah penelitian. 
Teknik analisis data yang dilakukan dalam penelitian adalah analisis kuantitatif dengan menggunakan statistik, yaitu statistik deskriptif dan statistik inferensial. Untuk mendapatkan deskripsi data sampel, peneliti menggunakan teknik statistik deskriptif, sedangkan untuk membuat simpulan yang berlaku untuk populasi, peneliti akan menggunakan statistik inferensial. Analisis deskriptif digunakan untuk mencari rata-rata dan varian, selanjutnya dilakukan uji prasyarat yaitu uji normalitas dan homogenitas. Setelah data dinyatakan normal dan homogen maka dilakukan analisis inferensial. Data penelitian ini dianalisis dengan menggunakan uji-t. Hasil analisis data sampel yang akan diberlakukan untuk populasi mempunyai peluang kesalahan dan kebenaran (kepercayaan) yang dinyatakan dalam bentuk persentase. Taraf signifikasi yang digunakan dalam penelitian ini adalah peluang kesalahan $5 \%$ atau $\alpha=0,5$ dan taraf kepercayaan $95 \%$.

Pengujian taraf signifikasi dari hasil analisis data sampel yang akan diberlakukan untuk populasi didasarkan atas statistik parametris dengan menggunakan t-test. Menurut Sugiyono (2013: 196), jika $\mathrm{n}_{1} \neq \mathrm{n}_{2}$ dan varian homogen, maka pengujian hipotesis dapat menggunakan rumus uji-t dengan pooled varian untuk dua sampel independent sebagai berikut:

Keterangan:

$$
\mathrm{t}=\frac{\overline{\mathrm{X}}_{1}-\overline{\mathrm{X}}_{2}}{\sqrt{\frac{\left(\mathrm{n}_{1}-1\right) \mathrm{S}_{1}^{2}+\left(\mathrm{n}_{2}-1\right) \mathrm{S}_{2}^{2}}{\mathrm{n}_{1}+\mathrm{n}_{2}-2}\left(\frac{1}{\mathrm{n}_{2}}+\frac{1}{\mathrm{n}_{2}}\right)}}
$$

$\mathrm{t}=$ Nilai $\mathrm{t}$ hitung

$\overline{\mathrm{X}}_{1}=$ Skor rata-rata pretest - posttest kelompok 1

$\overline{\mathrm{X}}_{2}=$ Skor rata-rata pretest-posttest kelompok 2

$\mathrm{n}_{1}=$ Jumlah sampel kelompok 1

$\mathrm{n}_{2}=$ Jumlah sampel kelompok 2

$\mathrm{S}_{1}^{2}=$ Varian kelompok 1

$\mathrm{S}_{2}^{2}=$ Varian kelompok 2

Jika nilai thitung $>$ tabel pada taraf signifikan 5\% dan derajat kebebasan $(\mathrm{dk})=\mathrm{n}_{1}+\mathrm{n}_{2}-$ 2, maka terdapat pengaruh yang signifikan. Berdasarkan analisis data dengan menggunakan uji normalitas dan homogenitas, statistik deskriptif, dan statistik inferensial di atas dapat disimpulkan apakah hipotesis diterima atau ditolak.

Kriteria untuk menguji hipotesis alternatif $\left(\mathrm{H}_{\mathrm{a}}\right)$, apakah hipotesis ditolak atau diterima dapat menggunakan hasil analisis data berdasarkan nilai $t_{\text {tabel }}$ pada taraf signifikan $5 \%$, jika thitung $>t_{\text {tabel }}$ maka $\mathrm{H}_{\mathrm{a}}$ ditolak dan jika thitung $\leq \mathrm{t}_{\text {tabel }}$ maka $\mathrm{H}_{\mathrm{a}}$ diterima.

\section{Hasil}

Adapun data hasil belajar kognitif yang didperoleh melalui pretest dan posttest siswa pada proses pembelajaran matematika dapat disajikan dalam tabel 1 .

Tabel 1. Analisis data Pretest dan Posttest Kelas Eksperimen dan Kontrol

\begin{tabular}{ccccc}
\multirow{2}{*}{ Deskripsi } & \multicolumn{2}{c}{ Pretest } & \multicolumn{2}{c}{ Posttest } \\
\cline { 2 - 5 } & Eksperimen & Kontrol & Eksperimen & Kontrol \\
\hline Nilai Tertinggi & 75 & 70 & 100 & 90 \\
\hline Nilai Terendah & 35 & 35 & 60 & 50 \\
\hline Jumlah & 1673 & 1597.5 & 2324 & 2079 \\
\hline Rata-rata & 59.75 & 55.09 & 83.00 & 74.25 \\
\hline
\end{tabular}




\begin{tabular}{ccccc}
\hline Standar Deviasi & 11.79 & 10.13 & 12.3 & 10.95 \\
\hline Varian & 139.157 & 102.628 & 151.407 & 119.905 \\
\hline $\mathbf{X}^{2}$ hitung & $\begin{array}{c}\text { (Normal) } \\
\text { F }\end{array}$ & $\begin{array}{c}7.09 \\
\text { (Normal) }\end{array}$ & $\begin{array}{c}8.42 \\
(\text { Normal })\end{array}$ & $\begin{array}{c}7.55 \\
\text { (Normal) }\end{array}$ \\
\hline thitung & 1.36 (Homogen) & 1.26 (Homogen) \\
\hline
\end{tabular}

Berdasarkan tabel di atas, hasil pretest menunjukkan nilai rata-rata kelas eksperimen (59.75) memiliki selisih dengan nilai rata-rata kelas kontrol (55.09), tetapi tidak terlalu signifikan sehingga kelas eksperimen dan kelas kontrol memiliki kemampuan yang hampir sama.

Sedangkan hasil posttest menunjukkan nilai rata-rata (83.00) kelas eksperimen lebih tinggi dari nilai rata-rata (74.25) kelas kontrol. Perbandingan rata-rata kelas eksperimen yang lebih tinggi dari kelas kontrol disebabkan adanya perlakuan yaitu penggunaan media manipulatif bangun ruang pada pembelajaran di kelas eksperimen sedangkan di kelas kontrol pembelajaran dilakukan secara konvensional.

\section{Pembahasan}

Penelitian yang telah dilakukan di kelas V SDN 52 Kota Bengkulu, diawali dengan memberikan pretest pada kelas eksperimen dan kelas kontrol untuk melihat kemampuan awal siswa. Dari hasil pretest diperoleh hasil belajar matematika siswa pada kelas eksperimen (VC) dan kelas kontrol (VA) menunjukan nilai rata- rata yaitu kelas eksperimen sebesar 59.75 dan kelas kontrol 55.09. Setelah dilakukan uji prasyarat normalitas dan homogenitas, kedua sampel tersebut dinyatakan berdistribusi normal dan memiliki kemampuan awal yang sama atau homogen sehingga dapat dilakukan penelitian pada kedua sampel.

Hasil posttest menunjukkan bahwa data berdistribusi normal dan homogen dengan rata-rata yaitu kelas eksperimen 83.00 dan kelas kontrol 74.25. Persentase kenaikan pada kelas eksperimen sebesar $38.91 \%$ sedangkan kenaikan pada kelas kontrol sebesar $33.57 \%$, kenaikan persentase nilai pada kelas eksperimen lebih besar daripada kelas kontrol terbukti perbedaan kenaikan hasil belajar kognitif sebesar 5.34\% (Lampiran 26 hal 138). Setelah dilakukan posttest selanjutnya dilakukan uji hipotesis, data hasil hipotesis antara kelas eksperimen dan kelas kontrol menunjukkan thitung lebih besar dari tabel artinya Artinya terdapat perbedaan yang signifikan pada kedua kelompok ini.

Perbedaan posttest pada kelas eksperimen dan kelas kontrol dikarenakan adanya perlakuan yang diberikan pada kelas eksperimen. Proses pembelajaran pada kelas eksperimen menggunakan media manipulatif, sedangkan pada kelas kontrol pembelajarannya dilakukan secara konvensional, tetapi untuk materi yang diajarkan sama yaitu jaring-jaring bangun ruang.

Pembelajaran di kelas eksperimen dilakukan dengan diskusi kelompok, siswa dibagi kedalam 5 kelompok secara heterogen. Dalam kelompok yang telah dibagikan masing-masing kelompok diberikan LDS mengenai unsur-unsur yang terdapat dalam bangun ruang dan media manipulatif yang dilegkapi dengan gunting, penggaris dan pensil untuk memudahkan anak memotong, merebahkan dan kemudian menjiplak jaring-jaring bangun ruang yang mereka dapatkan dari media manipulatif tersebut. Hal ini sesuai dengan penelitian Amira (2013) dengan judul "Pembelajaran Matematika SD Dengan Menggunakan Media Manipulatif" 
kesimpulan dari penelitian ini bahwa media manipulatif tidak hanya membantu memahami konsep-konsep dalam matematika, tetapi juga sebagai media untuk memecahkan masalah yang dihadapi.

Dalam diskusi siswa terlihat saling bekerja sama untuk memotong, merebahkan dan menjiplak jaring-jaring yang mereka temukan. Hal ini sesuai dengan Muhsetyo (2009: 2.20) yang mengemukakan media manipulatif dalam pembelajaran matematika SD adalah media yang dapat dimain-mainkan,dipegang, dipindahpindah, dipasang, dibolak-balik, diatur/ditata dan dilipat/dipotong oleh siswa. Ada siswa yang asik menggunting sambil mengotakatik media tersebut, ada yang berjalan untuk melihat hasil potongan teman-temanya, sehingga mereka terlihat aktif dan antusias karena terlibat langsung dan mulai menemukan konsep serta berfikir dari konkret menuju abstrak. Hal ini sesuai dengan penelitian M.Boggan dkk (2014) dengan judul "Using manipulatives to teach elementary mathematics" kesimpulan dari penelitian ini "menggunakan media manipulatif dalam pelajaran matematika dapat membantu siswa memahami konsep dan memungkinkan mereka unuk beralih dari pengalaman konkret ke penalaran abstrak.

Pembelajaran di kelas kontrol memiliki situasi yang berbeda dengan kelas eksperimen karena pembelajaran dilakukan secara konvensional. Pembelajaran dimulai dengan menggambarkan jaring-jaring bangun ruang dipapan tulis, memberikan materi kemudian melakukan diskusi kelompok dan diakhiri dengan melakukan tanya jawab tentang jaring-jaring bangun ruang.

Dengan memanipulasi media manipulatif ini siswa dapat menemukan sendiri konsep jaring-jaring bangun ruang. Hal ini sesuai dengan Brunner (Runtukahu: 2013: 69) menyatakan bahwa anak usia Sekolah Dasar berada pada tahap enaktif. Artinya pada tahap ini siswa langsung terlibat dalam memanipulasi obyek-obyek matematika, sehingga media manipulatif bermanfaat dalam proses pembelajaran jaring-jaring bangun ruang karena siswa akan terlibat langsung dan dapat menemukan konsep sendiri dalam proses pembelajaran.

Media manipulatif cocok digunakan dalam menemukan konsep karena disajikan dalam bentuk kongkret. Pada usia Sekolah Dasar, siswa berada pada tahap oprasional konkret artinya siswa dapat dengan mudah memahami materi dalam bentuk nyata. Hal ini sesuai dengan Piaget (Syah: 2015: 26) yang mengemukakan bahwa karakteristik siswa Sekolah Dasar berusia 7 sampai 11 tahun yang berada dalam tahap berpikir operasional konkret, pada tahap ini siswa baru mampu berfikir sistematis mengenai benda-benda dan peristiwa-peristiwa yang kongkrit.

\section{Simpulan}

Berdasarkan data hasil penelitian, pengolahan data dan pembahasan, maka dapat disimpulkan bahwa terdapat pengaruh penggunaan media manipulatif terhadap hasil belajar siswa pada pembelajaran matematika kelas V SDN 52 Kota Bengkulu. Hal tersebut dapat dilihat dari perbedaan antara hasil postest kelompok eksperimen dan kelompok kontrol. Perbedaan dapat dibuktikan dari hasil belajar kognitif siswa kelas V pada uji-t posttest, thitung lebih besar dari tabel. Secara sistematis dapat dituliskan thitung $(2,84)>t_{\text {tabel }}(1,625)$, Sehingga dapat disimpulkan bahwa $\mathrm{H}_{\mathrm{a}}$ diterima.

Perbedaan tersebut juga ditunjukkan dari perbedaan kenaikan hasil belajar kognitif sebesar 5.34\% setelah siswa mengikuti pembelajaran menggunakan media manipulatif, dimana siswa terarah menjadi aktif karena terlibat langsung dalam menemukan sendiri konsep jaring-jaring bangun ruang. 


\section{Saran}

Berdasarkan hasil penelitian yang dilakukan, maka peneliti memberikan beberapa saran sebagai berikut.

1. Bagi Guru

a. Dalam membentuk kelompok diskusi hendaknya membagi kelompok secara heterogen agar siswa terlibat seluruhnya tidak mendomisili yang memiliki kemampuan yang sama semua.

b. Dalam menggunakan peralatan untuk memotong media manipulatif, siswa perlu pengawasan yang cukup dan hindari penggunaan peralatan untuk memotong yang terlalu tajam agar tidak melukai siswa.

2. Bagi peneliti lain yang ingin menindaklanjuti

a. Disarankan peneliti untuk menemukan jaring- jaring berbagai bangun ruang yang lain dengan menggunakan media yang sama yaitu media manipulatif.

b. Peneliti menggunakan media manipulatif tetapi dengan mencoba materi yang berbeda

c.

\section{Referensi}

Bogan, M., H., S. \& Whitmire, A. 2013. Using manipulatives to teach elementary mathematics. http://www.aabri.com/manuscripts/10451.pdf, Diakses pada 15 November 2017.

Lubis, F. 2014. Pengaruh Media Manipulatif Pada Pembelajaran Matematika Terhadap Hasil Belajar Siswa Kelas V Sekolah Dasar. Jurnal Pendidikan dan Pembelajaran. Vol. 3. No 06. 2014.

Muhsetyo, G. dkk. 2007. Pembelajaran Matematika SD. Jakarta: Universitas Terbuka.

OECD. 2015. PISA 2015 results in focus. https://www.oecd.org/pisa/pisa-2015-resultsin-focus.pdf,Diakses pada 19 November 2017.

Rahmawati. 2016. Seminar Hasil TIMSS 2015. Tersedia dalam https://id.scribd.com/document/350697568/Rahmawati-Seminar-Hasil-

TIMSS-2015, Diakses 20 November 2017.

Runtukahu, J., T. \& Kandou, S. 2016. Pembelajaran Matematika Dasar Bagi Anak Berkesulitan Belajar. Jakarta: AR-RUZ MEDIA.

Sugiyono. 2013. Metode Penelitian Kuantitatid Kualitatif dan R\&D. Bandung: Alfabeta.

Sundayana. 2013. Media Dan Alat Peraga Dalam Pembelajaran Matematika. Bandung:ALFABETA.

Syah, M. 2015. Psikologi Belajar. Jakarta: PT. Raja Grafindo Persada.

Winarni, E., W. 2011. Penelitian Pendidikan, Bengkulu: Unit Penerbitan FKIP UNIB. 